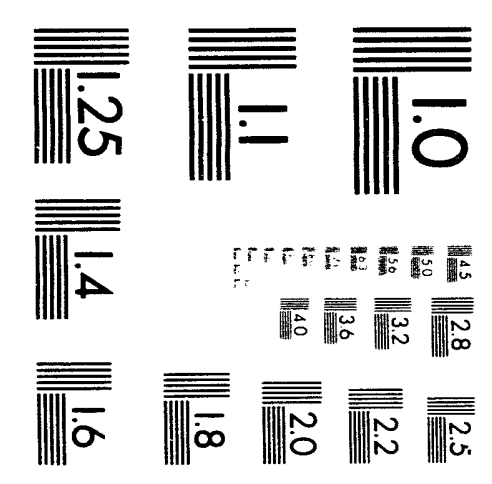



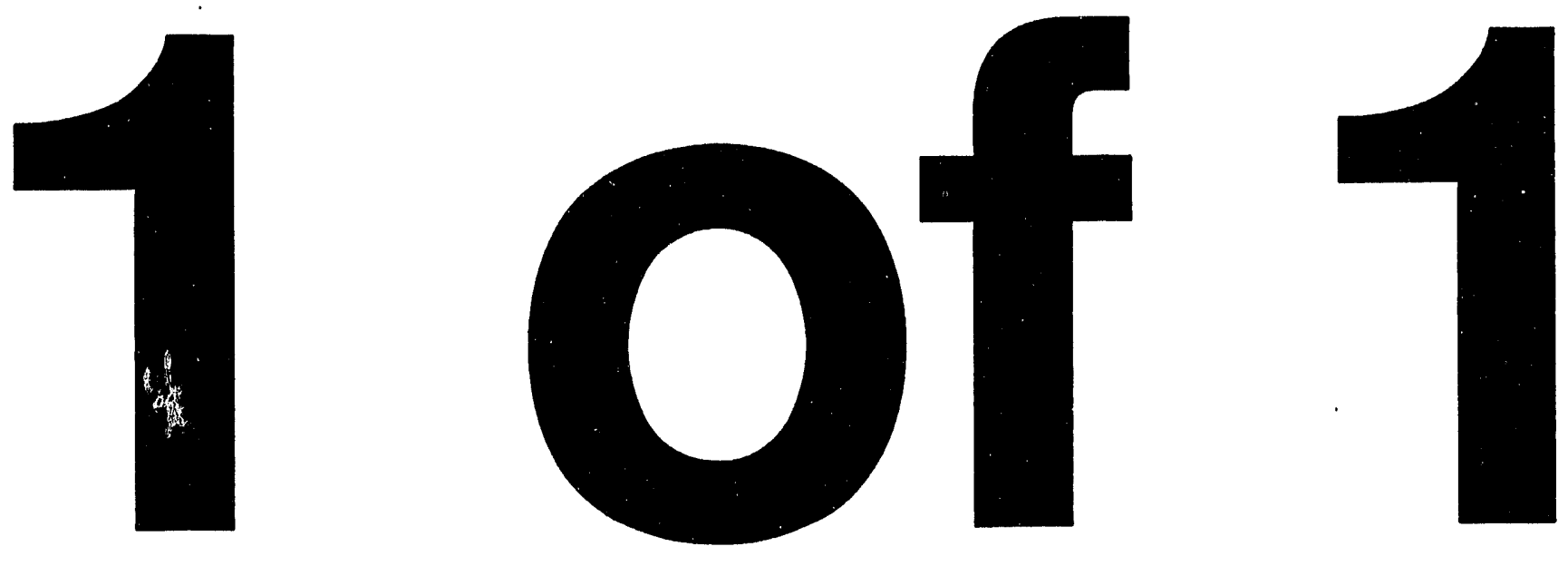


\title{
Factors Fragmenting the Russian Federation
}

\author{
E. Brown \\ LLNL Summer Employee
}

October 6, 1993

This is an informal report intended primarily for internal or limited external distribution. The opinions and conclusions stated are those of the author and may or may not be those of the Laboratory.

Work performed under the auspices of the U.S. Department of Energy by the Lawrence Livermore National Laboratory under Contract W-7405-Eng-48. 


\section{DISCLAIMER}

This document was prepared as an account of work sponsored by an agency of the United States Government. Neither the United States Governinent nor the University of California nor any of their employees, makes any warranty, express or implied, or assumes any legal liability or responsibility for the accuracy, completeness, or usefulness of any information, apparatus, product, or process disclosed, or represents that its use would not infringe privately owned rights. Reference herein to any specific commercial products, process, or service by trade name, trademark, manufactures, or otherwise, does not necessarily constitute or imply its endorsement, recommendation, or favoring by the United States Government or the University of California. The views and opinions of authors expressed herein do not necessarily state or reflect those of the United States Government or the University of California, and shall not be used for advertising or product endorsement purposes.

This report has been reproduced directly from the best available copy.

A vailable to DOE and DOE contractors from the Office of Scientific and Technical Information

P.O. Box 62, Oak Ridge, TN 37831

Prices a vailable from (615) 576.8401, FTS 626.8401

A vailable to the public from the

National Technical Information Service

U.S. Department of Commerce 5285 Port Royal Rd., Springfield, VA 22161 


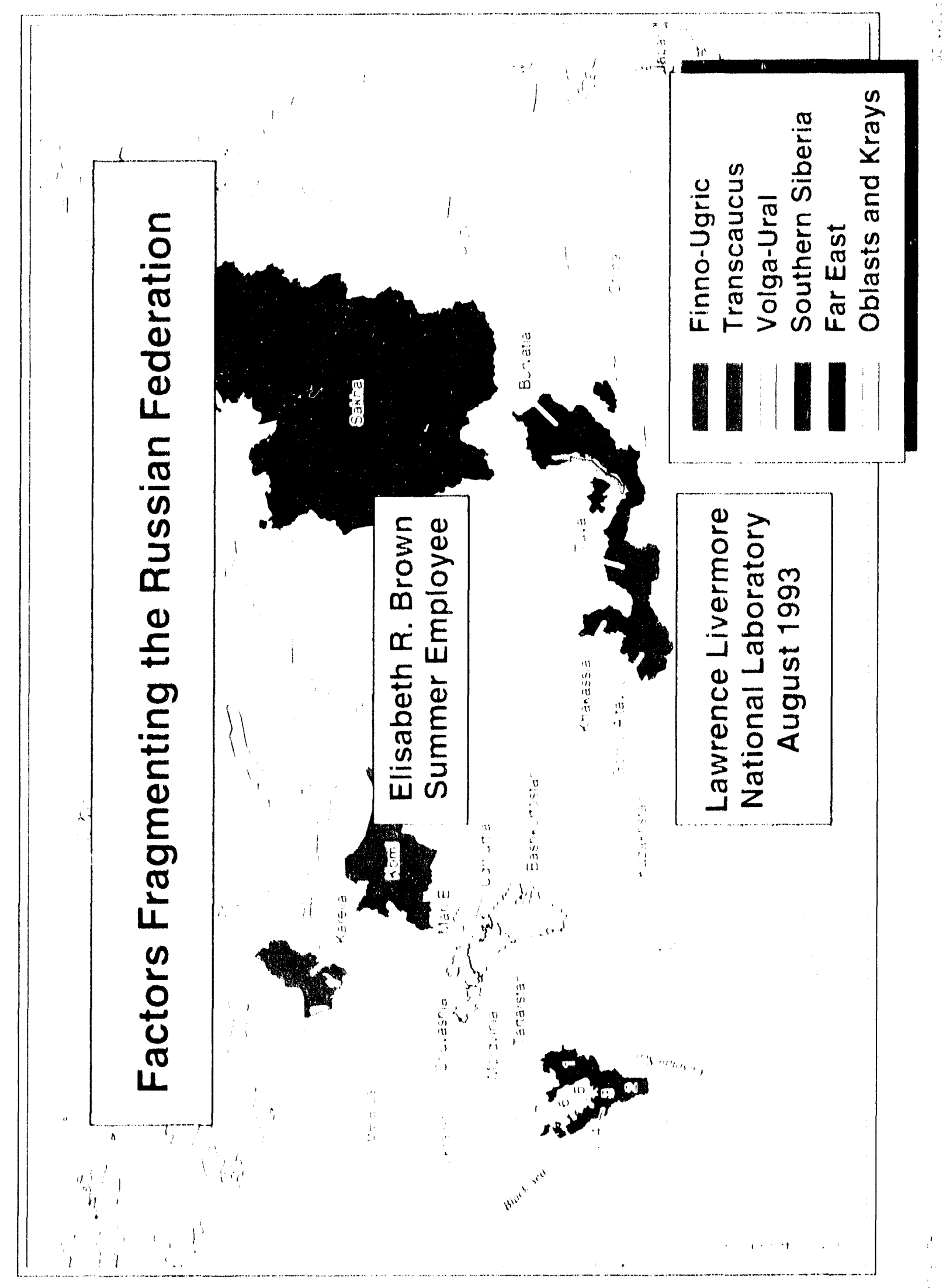

\section{Mastin}




\section{Factors Fragmenting the Russian Federation}

\section{Key Judgments}

The demands for increased independence from the regions and republics of the Russian Federation (RF) threaten the unity of the RF. The United States needs to be aware of the turmoil within the RF because it serves as a potential threat to U.S. security. The regionalism in the RF may result in the formation of new independent states that possess nuclear and military capabilities. Because of the proliferation that could result, this regionalism is extremely significant to U.S. policy.

The U.S. must monitor the regions and republics of the RF to determine the extent of independence they have achieved, as well as their military and nuclear capabilities. In determining the extent of independence, the U.S. should look at the motivations of the regions and republics seeking independence. The stronger the incentives, the more intense is the drive toward independence. For example, some regions and republics stand to gain more economically from independence than others do. This is because many regions and republics possess the wealth to be independent, whereas others are dependent on the federal government (the center) for subsidies, which limits their independence prospects. The primary motivations the U.S. should look for are:

- Does the region or republic stand to gain from economic autonomy?

- Is the region or republic treated on unequal terms by the center?

- Does the region have extremist nationalist movements that are directing the path of the local government?

The U.S. must form its policy in such a way that when dealing with individual regions and republics it is aware of whether the region or republic is effectively acting as an independent entity. The U.S. must be aware of this status to avoid mistaking the policy of the region or republic as consistent with the policy of the center. On the other hand, the U.S. must be circumspect before recognizing a region or republic as independent because this may compromise U.S. relations with the center. Recognition by the U.S. would be internationally significant and would lend legitimacy to an independence declaration that would otherwise lack credibility. By properly monitoring the political and economic situations in these regions and republics the U.S. can avoid over- and underreacting. 


\section{Factors Fragmenting the Russian Federation}

\section{Introduction}

The collapse of the Soviet Union in 1991 may not have been completely resolved by the formation of the Russian Federation (RF). Some of the continuing threat lies with the instability created by the much publicized power struggle between President Boris Yeltsin and the Russian parliament. Two other factors pose a fundamental threat to the RF's territorial integrity. The first is the inequality between the regions* and the republics, which is codified in the Federation Treaty and the draft constitution. The second is the economic benefits that the republics and regions stand to gain with increased independence from the center. The potential disintegration of the RF is not readily recognized by outside observers. It is a common mistake to perceive another country as more centralized than it actually is. ${ }^{1}$ The casual observer may wrongly perceive that a country is working as a cohesive, single actor, and that the state and the sum of its parts are adhering to the same policies. With its territorial integrity at stake, the RF is far less unified than one might assume. In fact, all 21 republics have declared sovereignty. ${ }^{2+}$ Outsiders need to be aware that the policy of a republic or region may not reflect the policy of the RF.

An underlying power struggle is being waged between the 21 republics of the RF, the 67 regions, and the center. When President Yeltsin was rallying support from the regions and republics for Russia's autonomy from the Soviet Union, he told the republics: "Take all the sovereignty you can swallow." 3 Today, these words haunt him. The aim of the regions and republics is to acquire more independence and selfrule. The degree to which they demand independence varies. A likely future for the $\mathrm{RF}$ is a combination of three changes: some republics will choose to remain a part of the RF with increased sovereignty, others will be totally independent (e.g., Chechenya), and others will achieve confederal relations with the center. It is unlikely that all the republics and regions will choose the same direction. The diverse goals of the republics make the future unity of the RF uncertain.

This paper examines the factors that threaten the future of the RF. The observations are based on a study that focused on eight republics: Mordova,

* The term regions applies to the oblasts (provinces) and krays (areas) of the RF.

1 Robert Jervis, "Hypotheses in Misperceptions," World Politics, Vol 20, April 3, 1988.

2 Ann Shechy, "Russia's Republics: A Threat to its Territorial Integrity," RFE/RL Research Report, p. 34, May 14, 1993.

† Sovereignty means constitutional separateness, and within a sovereignty no other entity can enforce any laws unless the sovereign entity consents to them. The sovereign entity has total internal autonomy.

3 Richard Boudreaux, "A Nation of Law, at Last?" Los Angeles Times, p. 1, col. 2, May 25, 1993. 
Udmurtia, Tatarstan, Mari El, Bashkortostan, Kabardino-Balkaria, Buryatia, and Altay Republic. These republics were selected for their geographic and economic significance to the RF. Tatarstan, Bashkortostan, Udmurtia, and Mari El are located on important supply routes, such as the Volga River and the trans-Siberian railroad. Some of these republics are relatively wealthy, with natural resources such as oil (e.g., Tatarstan and Bashkortostan), and all eight republics play significant roles in the military-industrial complex. The importance of these republics to the RF contrasts to the relative insignificance of the independence-minded Northern Caucasus area. We chose not to examine the Northern Caucasus region (except Kabardino-Balkaria) because these republics may have only a minor impact on the rest of the RF if they secede. Their impact would be minimized because they lie on the frontiers of the RF (see Fig. 1). Many Russians believe that "it might be best to let such a troublesome area secede." 4

This paper focuses first on the Federation Treaty and the draft constitution to examine the relations between and among the center and the republics and regions. The Federation Treaty and the draft constitution delineate the powers between the republics and the center. The inequality between the regions and republics is detailed in these sections. An in-depth study of the Republic of Tatarstan gives an indication of one path that regions and republics could take toward independence. In the example of Tatarstan, the economic benefits of independence are made evident. Although Tatarstan's path is not the only option for regions and republics, it does illustrate how fragile the unity of the RF is. Because Tatarstan is one of the more advanced of the republics and regions on the road to independence, its success in achieving independence and establishing itself as an economically viable country could set a precedent that others will follow (see Tables 1 and 2). The positions of other republics are discussed in the Appendix.

\section{Confederation Treaty}

President Yeltsin and representatives of the legislative and executive branches of 18 of the then 20 republics** approved the Federation Treaty on March 31, 1992. The purpose of the document is to establish a framework that defines the relation between the center and its republics. This specific treaty does not apply to the regions. All of the republics signed the Federation Treaty, except Tatarstan and Chechenya-Ingushetia, although the center has not yet implemented the Treaty. ${ }^{5}$

\footnotetext{
4 Ann Shechy, "Russia's Republics: A Threat to Its Torritorial Integrity?" RFE/RL. Research Report, p. 40, April 30, 1993.

* Chechenya-Ingushetia has since become two separate republics.

5 Ann Shechy, "Russia's Republics: A Threat to its Territorial Integrity?" RFE/RL Research Report, p. 38, May 14, 1993.
} 


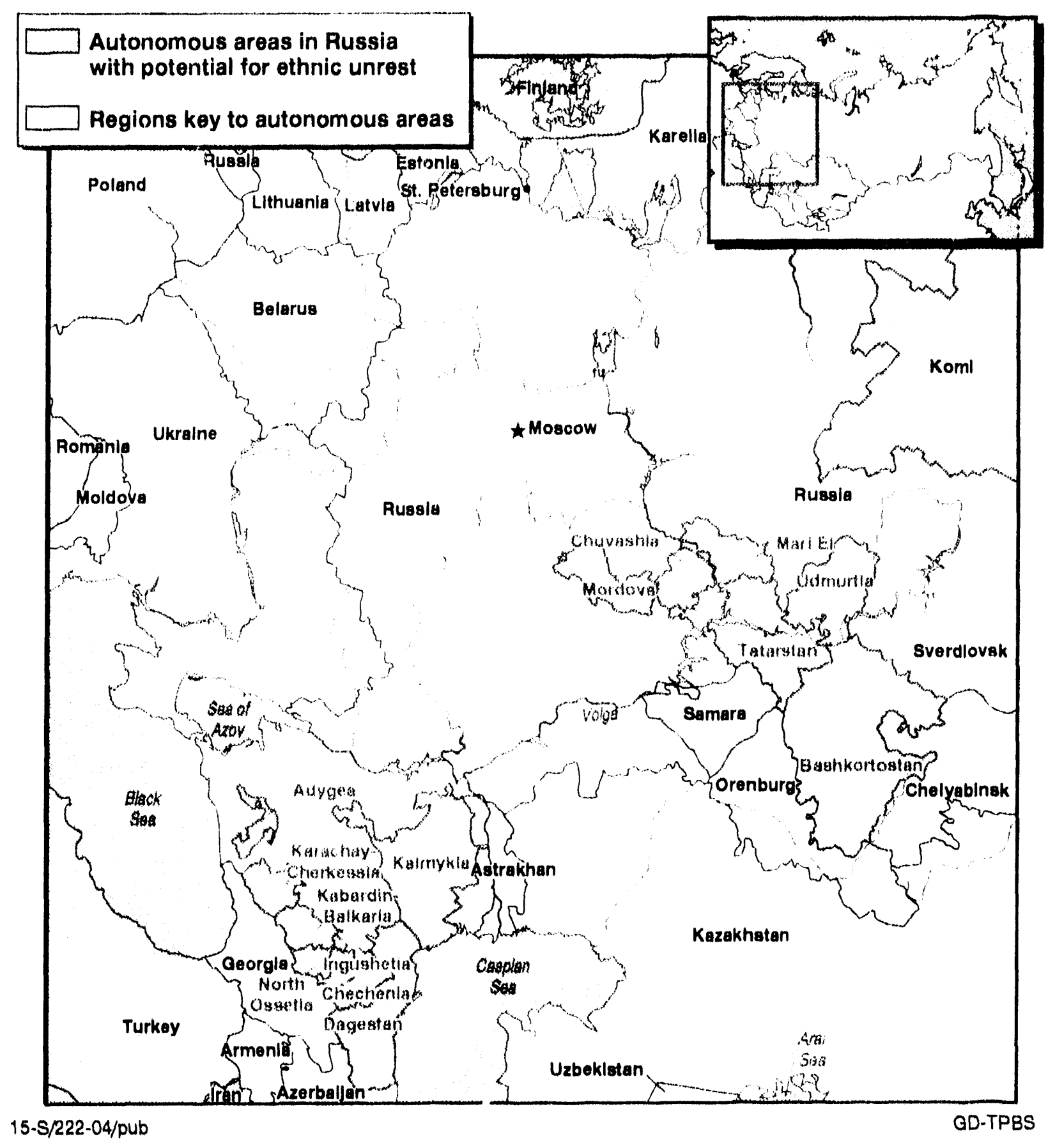

Figure 1. Trade routes for Tatarstan. 
Table 1. Independence indicators.

* Tatarstan does not have its own military, but it is making its own decidions concerning the military. For example, troops from Tatarstan may serve only within Tatarstan and the Volga-Ural military district.

\begin{tabular}{|c|c|c|c|c|c|c|}
\hline & $\begin{array}{l}\text { clared } \\
\text { reignty }\end{array}$ & $\begin{array}{c}\text { Own } \\
\text { Constitution }\end{array}$ & $\begin{array}{l}\text { With holding } \\
\text { taxes } \\
\text { from center }\end{array}$ & $\begin{array}{l}\text { Own } \\
\text { military }\end{array}$ & $\begin{array}{c}\text { Conflict } \\
\text { in laws } \\
\text { with center }\end{array}$ & $\begin{array}{l}\text { Demand: } \\
\text { own } \\
\text { currency }\end{array}$ \\
\hline Tatarstan & $Y$ & $Y$ & $Y$ & $Y^{*}$ & $Y$ & $Y$ \\
\hline Bashkortostan & $Y$ & $Y$ & $Y$ & $\mathbf{N}$ & $Y$ & $Y$ \\
\hline $\begin{array}{l}\text { Kabardino- } \\
\text { Balkaria }\end{array}$ & $Y$ & $Y$ & $N$ & $Y$ & $Y$ & $N$ \\
\hline Mordovia & $\mathrm{Y}$ & $Y$ & $N$ & $N$ & $Y$ & $N$ \\
\hline Udmurtia & $Y$ & $Y$ & $N$ & $N$ & N & $N$ \\
\hline Mari El & $\mathrm{Y}$ & Y & $N$ & $N$ & - & $N$ \\
\hline Buryatia & $\mathrm{Y}$ & $\mathrm{Y}$ & $N$ & $N$ & - & $N$ \\
\hline Altay Republic & $\mathrm{Y}$ & $\mathrm{Y}$ & $\mathrm{N}$ & $N$ & - & $N$ \\
\hline
\end{tabular}

Table 2. Degree of independence achieved.

* The numbers on the left represent the total number of independence indicators in which the republics were displaying activity. Assuming that each indicator is equal, then Tatarstan is the most active in pursuing independence.

\begin{tabular}{cc|}
\hline 6 & Tatarstan \\
$\mathbf{5}$ & Bashkortostan \\
$\mathbf{4}$ & $-{ }^{*}$ \\
$\mathbf{3}$ & Mordava, Buryatia, and \\
& Kabardin-Balkaria \\
$\mathbf{2}$ & Udmurtia, Mari El, \\
& and Altay Republic \\
$\mathbf{1}$ & -
\end{tabular}


In the Treaty, the center retains control over national defense and security while it gives more local control to the republics to keep them from seceding. ${ }^{6}$ The center's authority includes defense production and the trading of any military equipment. The center needs this as an important sign of a stable state. ${ }^{\text {t+ }}$ However, the center's control over defense is diminishing as some of the republics are trying to make decisions on military matters. For example, the Republic of Tatarstan has issued a law that Tatar troops serving in the Russian military can only serve on Tatarstan's territory and in the Ural-Volga military district. ${ }^{7}$ Tatarstan also issued a draft declaration on March 4, 1993 that if adopted would make the territory neutral. ${ }^{8}$ This effort to control defense-an area of government traditionally held by the centerreveals the extent to which the stability of the RF is at stake.

In addition to defense and security, the center has power over its own budget and controls the federal energy systems (e.g., nuclear power plants), federal transportation (railways), space activities, and international treaties. ${ }^{9}$

The Treaty outlines powers that the center and republics share. For instance, they must agree on a common principle of taxation, provide education and health care, and ensure that the laws and constitutions of the republics conform to the laws and the constitution of the RF.10 This contradicts the principle of sovereignty that the republics require. They must sacrifice their sovereignty by subordinating their constitutions to that of the center. At least nine republics defy this contradiction to their sovereignty by stating in their constitutions that the local laws will be supreme to the federal laws. These nine are Bashkortostan, Buryatia, Chechenya, Kalmykia, Karelia, Mordova, Sakha, Tatarstan, and Tuva." 11

Nonetheless, many republics believe the powers granted to them in the Federation Treaty imply sovereignty. ${ }^{12}$ These powers include legislative, executive, and judicial authority within each of their territories. However, their powers remain under the framework of and are subordinated to the Russian constitution. The Treaty allows the republics to pursue independent international economic activity, but it qualifies what constitutes independent activity. The economic activity

6 Elizabeth Shogren, "Russia Signs a Pact with 18 of Its 20 Republics," Los Angeles Times, p. 1, April 1, 1992.

t+ All stable states have a monopoly on the legitimate use of force. If regions and republics acquire their own military forces, then a stable state is suspect.

7 "Report on Tatarstan Parliament Session Activity," FBIS-USR, p. 50, June 10, 1992.

8 "Tatarstan Develops Draft Declaration on Neutrality," FBIS-SOV, p. 40, March 4, 1993.

9 "Central Eurasia Constitutional Commission's Draft Constitution-Chapter XIII (Federal Treaty)," Foreign Broadcast Information Service Daily Report Supplement, p. 11, May 13, 1993.

10 Ibid., p. 12.

11 Vladimir Yemelyanko, "The Country Will Collapse," Muscoie News, February 7, 1993.

12 "Yeltsin's Wooing of Republics on Constitution Mects Trouble," FBIS Trends, p. 24, May 26, 1993. 
cannot conflict with the federation's constitution, and the republic can only pursue it in conjunction with the federal organs of state power. ${ }^{13}$

The republics believe that because they adopted the Treaty voluntarily, they have a right to secede. ${ }^{14}$ If this is so, it somewhat preserves the sovereignty of the republics."

\section{The Draft Constitution}

The draft constitution, as approved by the constitutional assembly on July 12, 1993, has a very slim chance of approval by the regions and republics, because it codifies the unequal status of the RF's republics and regions. Although the republics are the privileged ones in this unequal relationship, they are still unhappy with the draft constitution because it eliminates the sovereignty they believed the Federation Treaty provided.

The Constitutional Assembly approved the draft constitution with a vote of 433 to 152.15 However, this does not mean the constitution is official; a process for adopting the constitution must be agreed upon.15 Some people believe the Congress of People's Deputies should adopt it, because that is what the current constitution stipulates. The draft constitution, however, calls for abolishing this congress, so the chances of it passing the constitution are remote. ${ }^{17}$ Another suggestion is to hold a national referendum to adopt it. 18 The most likely option is to have the regions' and republics' soviets approve or reject it.

There are several obstacles that threaten the adoption of the constitution. The first is a conflict between the regions and the republics. The regions resent the privileged position that the republics have, and they demand at least equal status with the republics. ${ }^{19} \mathrm{As}$ it stands in the draft constitution, regions are territorialstate formations that, when dealing with the center economically or politically, have identical rights with the republics. ${ }^{20}$ This identical-rights clause came after much

13 "Central Eurasia, Constitutional Commission's Draft Constitution-Chapter XIII

(Federal Treaty)," Foreign Brondcast Information Service Daily Report Supplement, p. 13, May 13, 1993.

14 "Following the French," The Economist, p. 59, June 12, 1993.

* For example, the members of the European Community delegate decision-making powers to the community. However, they retain their sovereignty because they have the right to withdraw from the community.

15 Vera Tolz, "Constitutional Assembly Approves Draft Constitution," RFE/RL Daily Report, No. 131, July 13, 1993.

16 Press Conference by RF Presidential Political $\Lambda d v i$ sor Sergei Stankevich, June 17, 1993.

17 David Ljunggren, "Yeltsin Goes on Holiday to Think out Next Moves," The Reuter Library Report, July 13, 1993.

18 "Buryat Leaders Favor Referendum on Combined Draft," FBIS-SOV, pp. 41-42, May 26, 1993.

19 Op. cit.

20 Ann Sheehy, "Rights of Subjects of Federation Recognized?" RFE/RL Daily Report, No. 117, June 23, 1993. 
chagrin on the part of the regions over their lower status. However, many regions believe the identical rights clause is insufficient. This is because the constitution still defines republics as sovereign states within the RF, whereas the regions are not so defined. 21

The republics' privileged status gives them more control over their economic and political lives. The regions also desire local control so that they can benefit more from their economic potentials, such as natural resources, and pass laws that are favorable to themselves. ${ }^{22}$ The regions find the status of the republics especially unfair considering that many regions have larger populations and larger economies than many of the republics. ${ }^{23}$ For example, the republics constitute only $29 \%$ of Russia's territory and $15 \%$ of the population. Yet, in the originally proposed draft constitution the Federation Council, which would be the upper house of the potential new parliament, the republics would occupy $50 \%$ of the seats. ${ }^{24}$ However, because of the regions' overwhelmingly negative reaction, this was changed so that each region and republic would have two representatives in the upper house. ${ }^{25}$ The regions also resent that they carry a heavier tax burden, which is used to subsidize the republics. 26

The unequal status between regions and republics originates from the ethnic nature of the republics. The purpose of the republics is to give a degree of political autonomy to ethnic mi orities in the RF. The privileged status of the republics was tailored to stem separatist tendencies within these ethnically different regions. ${ }^{27}$

Several regions have decided to gain the privileged status of the republics by declaring themselves to be republics. The first to do so was Sverdlovsk Oblast. The Sverdlovsk Oblast is not interested in preserving a minority culture. Instead it seeks to reap the same benefits, primarily economic, that the republics receive because of their unequal status in the constitution. On July 1, 1993, Sverdiovsk Oblast declared itself to be the Ural Republic. 28 On the April 1993 Yeltsin referendum, the Oblast included a question asking the people if they wanted to be elevated to the status of a republic. ${ }^{29}$ The people were in favor of this transformation. Considering that

21 "Two Russian Regions Strike Blow Against Yeltsin," The Reuter Library Report, July 14, 1993.

22 Andrew Higgins, "Meek revolt transforms Sverdlovsk..." p. 9, July 14, 1993.

Mike Trickey, "Russian constitution a step closer," The Ottawa Citizen, Section: News; p. A8, July 13, 1993.

23 Ibid. (Mike Trickey).

24 "Following the French," The Economist, p. 59, June 12, 1993.

25 Ann Sheehy, "Regions Object to Higher Status of Republics," RFE/RL Daily Report, No. 120, June 28, 1993.

26 David Ljunggren, "Yeltsin Goes on Holiday to Think out Next Moves," Reuters, July 13, 1993.

27 Elizabeth Shogren, "Russia Signs Pact with 18 of its 20 Republics," Los Angeles Times Home Edition, p. 1, Pt. A, col. 3, April 1, 1992.

28 Ann Shechy, "Sverdlovsk Oblast Declares Itself Ural Republic," RFE/RL Daily Report, No. 124, July 2, 1993.

29 Ibid. 
Sverdlovsk is predominantly ethnic Russian and the home region of Boris Yeltsin, its decision is significant. It shows that reasons other than national identity are important in the desire to gain the status of a republic. Sverdlovsk is not the only region to covet the benefits of the republics. The city of Vologda has also declared itself to be a republic. ${ }^{30}$ Others are likely to follow suit.

The regions' dissatisfaction with the constitution is not unique. While the regions complain that the republics have too many privileges, the republics demand even more privileges. For instance, Egor Larionov, the deputy chairman of the parliament of Sakha, recognized that the clause calling the republics sovereign states is without effect, considering that the draft constitution continues the Federation Treaty's subordination of the republics' constitutions. ${ }^{31}$ In addition, the draft constitution does not give the republics the right to secede. ${ }^{32}$

There is a proposal that could possibly ameliorate the conflict between the republics and the regions, and gain their support for the constitution. ${ }^{33}$ This would be to grant the republics the ability to form bilateral treaties directly and separately with Moscow. Under this proposal, the regions would receive the authority to make their own laws and form their own charters. Although this would not give them equal political power, it could alleviate the difficulties. However, it would contradict the constitution's current proposal granting the republics and regions equal rights when dealing with the center, because under the new proposal, the republics would have the additional power of forming treaties.

\section{Example: Tatarstan}

A focused look at a specific republic may give a better idea of a republic's pursuit of independence, and thus illustrate that the RF is a conglomerate of many entities pursuing different objectives.

Tatarstan's bid for independence is a credible one because of its oil wealth, as well as its manufacturing of marketable goods such as trucks. Although the republic is geographically surrounded by the RF, Tatarstan is situated on important supply routes-for example, the Volga River and the trans-Siberian railroad. In addition, Yeltsin decreed in May 1992 that the center would not enforce a "quiet blockade" around Tatarstan, potentially giving Tatarstan access to the world. ${ }^{34^{*}}$ If peaceful separation from the center occurs, and Tatarstan does not provoke the center to abrogate this decree, then Tatarstan's geographical location may not be an obstacle to

30 Vladimir Orlov, "Are the 'New Russian Republics' Lawful?" Moscow News, July 14, 1993.

31 Vera Tolz, "Republics and Regions Unhappy about Draft Constitution," RFE/RL Daily Report, No. 131, July 13, 1993.

32 Ann Sheehy, "Status of Republics and Draft Constitution," RFE/RL Daily Report, No. 119, June 25, 1993.

33 Mike Trickey, The Ottawa Citizen, July 13, 1993.

34 Viktor Radziyevsky, "Tatarstan, Bashkortostan and the Federation Treaty," Moscow News, May 6, 1992.

* The writer interprets "quiet blockade" to mean an economic blockade (e.g., finance and trade). 
independence. However, the threat that the decree could be revoked will always loom over Tatarstan, giving the republic an incentive to achieve an independence that is acceptable to the center. On the other hand, the center has an incentive not to revoke the decree, because Tatarstan could use its location to disrupt the flow of the center's goods by not allowing goods to travel on the railroad through the republic.

Tatarstan has its own parliament and president. The personal leadership of President Shaymiyev lends credibility to Tatarstan's efforts toward independence by his centrist approach to government. Tatarstan's population requires a centrist approach to maintain stability between its ethnically diverse population of Tatars $(50 \%)$ and Russians (43\%). ${ }^{35}$ Within the Tatar population, there are extremists who demand total independence from the RF (e.g., Ittifak). Within the Russian population, there are people who remain intensely loyal to the RF. While the centrist approach of President Shaymiyev alienates the extremes, it is supported by the majority of the population. ${ }^{36}$

What makes Shaymiyev's approach attractive is that the forces for independence are economic, not nationalistic. Economic forces attract Russians and Tatars alike. In addition, Shaymiyev is pursuing a path to seek agreement and to accommodate rather than alienate the center. ${ }^{37}$

Tatarstan has taken the following steps toward independence.

- August 30, 1990-The republic declared sovereignty. ${ }^{38}$

- April 18, 1991-The constitution was altered so that Tatarstan was no longer a member of the RF. ${ }^{39}$

- March 1992-Sixty-one percent of the voters favored gaining economic independence and becoming subject to international law, and therefore an entity separate from the RF. ${ }^{40}$ Shaymiyev took these results as a mandate to open missions in several foreign countries, including all the CIS states, the United States, France, Japan, Saudi Arabia, and others. ${ }^{41}$

Tatarstan truly plans to become an international participant.

35 Georgi Vachnadze, "Russia's Hotbeds of Tension," Russian Draft, Marburg: Blaue Horner Verlag, p. 116, 1993.

36 Viktor Churilov and Aleksandr Kuteynitsm, "Our Intentions are Pure, and Our Path Just," FBIS-USR: Tatarstan, p. 3, Feb. 16, 1993.

37 "Yakutia, Tatarstan Want Independence Recognized," FBIS-USR, pp. 38-39, May 26, 1993.

38 "Tatar Supsov Chairman on Upcoming Independence Referendum," FBIS-USR, p. 111, March 27, 1992.

39 "Constitutional Court Decision on Tatar Sovereignty: On Amendments and Additions to the Constitution of the Tatarstan Republic," FBIS-LISR, p. 85, April 3, 1992.

40 "Observers on Conduct of Tatar Referendum," FBIS-USR, pp. 56-57, April 8, 1992.

41 "Tatar President's Decree to Set Up Diplomatic Missions Abroad," FBIS-USR, p. 29, May 4, 1992. 


\section{Tatarstan's Relations with the Center}

By May 6, 1992, President Yeltsin recognized that the center and the Tatar republic required a special treaty to define their relationship..$^{42}$ Currently, Tatarstan and the center are working to conclude such a treaty. Tatarstan's goal is not to secede totally from the center, but the republic demands the mutual delegation of powers between the center and the republic. ${ }^{43}$ In other words, Tatarstan seeks equal status. Tatarstan proposes to delegate powers such as national defense, space research, transportation, and energy to the center. ${ }^{44}$ In return, the center would delegate real sovereignty to Tatarstan.

As of June 23,1993, the expectation was that the bilateral treaty between the two would be completed in July. ${ }^{45}$ Tatarstan demanded that the treaty be included in the $\mathrm{RF}^{\prime}$ ' constitution, or Tatarstan would refuse to adopt this constitution. ${ }^{46}$ However, the draft constitution does not refer to any particular treaty, partly because one remains to be agreed upon. Consequently, Tatarstan threatened to recall its representatives from the constitutional assembly. ${ }^{47}$

The center and Tatarstan have different opinions of the relations they envision. Tatarstan requires the treaty to make the republic equal with the RF.48 Tatarstan demands to be a sovereign state that is its own agent in international affairs, that is "associated with Russia through a bilateral accord." 49 On the other hand, the center envisions Tatarstan as a sovereign state that "is incorporated in the RF and an agent in international law." 50 Therefore, the two must resolve the difference between associated and incorporated before they can conclude a satisfactory agreement. Incorporated implies that the center is still the supreme leader and that Tatarstan remains an official part of the $\mathrm{RF}$, despite being subject to international law. Associated implies a partnership of equals in which one partner delegates one responsibility to the other and vice versa. If Tatarstan is able to achieve this treaty, the chances are that other republics will demand a similar relationship. ${ }^{51}$

Both have agreed that before actually signing the major treaty, they will adopt eleven issue-specific treaties. These issues range from culture and education to scientific research, joint economic activity, and the environment. As of May 27,

42 "Yeltsin Reported to Acknowledge Special Russian-Tatar Relations," FBIS-USR, p. 65, June 3, 1992.

43 "Tatarstan's President Shaymiyev Interviewed," FBIS-SOV, p. 34, May 1, 1992.

44 "Report on Shaymiyev Address to Tatarstan Supsov," FBIS-USR, p. 51, June 10, 1992.

45 Ann Sheehy, "Tatarstan Still Insisting on Acknowledgment of its Special Status," RFE/RL Daily Report, No. 117, June 23, 1993.

46 Ibid.

47 Ann Sheehy," Tatarstan to Boycott Constitutional Assembly," RFE/RL Daily Report, No. 119, June 25, 1993.

48 "Tatar Supsov Chairman on Upcoming Independence Referendum," FBIS-USR, p. 111, March 27, 1992.

49 "Tatar President Denies Accord to be Signed with Moscow," FBIS-SOV, p. 50, March 8, 1993.

50 lbid.

51 "Things Fall Apart," The Economist, p. 47, January 30, 1993. 
1993, they had agreed on four such treaties, which dealt with environmental protection, property, and the sale and transportation of oil. 52

The center has shown that it intends to uphold its promise that Tatarstan will be an independent agent in international law. This is evident because the center allows Tatarstan to have separate offices and representatives in Russian embassies. ${ }^{53}$ By allowing Tatarstan to have its own diplomatic representation, the center displays a commitment to establishing an agreement with Tatarstan. Tatarstan is capitalizing on its ability to form political ties with foreign countries. Negotiations are underway with several countries on unspecified subjects. Such countries include the United States, France, Japan, Turkey, and Syria.54 The willingness of these countries to pursue agreements with Tatarstan reveals that Tatarstan has a degree of international credibility and adds legitimacy to Tatarstan's goal of independence.

Tatarstan demands the exclusive right to tax its people and corporations, and has stopped paying taxes to the center. The center's official policy on taxation is that the center collects all tax revenue, and then appropriates the revenue to the republics and regions. For example, the center appropriates about 60 percent of the revenue from excise taxes (alcoholic beverages, tobacco products, and some luxury items) to the republics, and retains 40 percrnt. ${ }^{55}$ The center can earmark the appropriated revenue for specific purposes, thereby limiting the budgetary options for the republics' government. Now, Tatarstan collects taxes and then gives some of the revenue to the center in payment for services, such as defense. This gives Tatarstan more control over its budget. 56

Another demand of Tatarstan's government is for independent economic activity. In 1992, the center approved the export of five million tonnes of oil from Tatarstan. ${ }^{57}$ This shows that the center allows Tatarstan some foreign economic activity. On the other hand, the fact that Tatarstan needed approval reveals that the center continues to exercise some control over Tatarstan's economy. With independent economic activity, Tatarstan would benefit from increased revenues by collecting its own tariffs. 58 In addition, with direct international trade, the republic would receive hard currency-the currency of preference over a constantly inflating ruble. In lieu of hard currency, Tatarstan's citizens are buying trucks manufactured by KamAZ and using these as a surrogate hard currency. ${ }^{59}$ Tatarstan intends to issue

52 "Tatarstan President Praises Mecting with Yeltsin," FBIS-SOV, pp. 58--59, June 2, 1993.

53 "Yeltsin Reported to Acknowledge Special Russian-Tatar Relations," FBIS-USR, p. 65, June 3, 1992.

54 "Supsov Chairman Address to Congress of Peoples of Tatarstan," FBIS-USR, p. 50, June 26, 1992.

55 Christie I. Wallich, Fiscal Decentralization: Intergonernmental Relations in Russia, p. 29, The World Bank, Washington, D.C., 1992.

56 Op. cit.

57 Georgi Vachnadze, p. 109.

58 Christine 1. Wallich, Fiscal Decentralization: Intergonernmental Relations in Russia, p. 29, The World Bank, Washington, D.C., 1992.

${ }^{59}$ Georgi Vachnadze, p. 105. 
its own currency to avoid the unstable ruble altogether, as well as to continue the process of separating itself from the center. ${ }^{60}$

Economic autonomy would allow Tatarstan to obtain a better price for its oil in the world market than the price it receives from the center. An illustration of this is that the center supplies Ukraine with oil at a price equivalent to $\$ 80$ a ton, well below the world price of $\$ 120$ a ton. ${ }^{61}$ Also, diversity of trading partners will reduce Tatarstan's reliance on the center, which is an unreliable trading partner. For instance, in 1992 Tatarstan made an agreement with the center to provide half its oil in return for oil extracting equipment. The center failed in its part of the deal; it provided only half the equipment that was agreed upon..$^{62}$ The center also proved to be an unreliable trading partner with Lithuania when it failed to supply a promised 2.4 million tonnes of oil in 1992. Now, Lithuania looks directly to Tatarstan for oil, to avoid the center.63

An important concession that increased Tatarstan's economic autonomy was that the center delegated control of ihe republic's customs authority to Tatarstan. This allows Tatarstan to trade with foreign countries more easily. In addition, the center and the republic signed a military agreement that enables weapon manufacturers in Tatarstan to export independently to other countries. The combination of these two agreements can be problematic from a proliferation standpoint because, with an independent customs service, it will be more difficult to monitor the flow of military materials and technology from the republic. ${ }^{64}$

Tatarstan separates itself from the center by pursuing a more gradual pace of economic reform. This is beneficial to Tatarstan's politicians, because the people believe gradual reform is better than the quick reform that President Yeltsin promotes. ${ }^{65}$

As an indication that Tatarstan will not settle for less than independence, 80 percent of the electorate did not vote in the referendum on confidence in support of Yeltsin. ${ }^{66}$ The people sent a signal to the center that they do not consider themselves a part of the RF and therefore will not participate in nationwide elections.

The relations with the center show a combination of Tatarstan working together with the center to form a treaty and pushing ahead separately to establish its own independent character.

\footnotetext{
60) Ann Shechy, "Deputy Premier Fedorov on Demands of Republics," RFE/RL. Daily Report, June 199.3.

61 Keith Bush, "Russia and Ukraine Agree on Oil Price," RIE/RL., No. 130), July 12, 1993.

62 Coorgi Vachnadzo, p. 126.

6.3 Ibid., p. 124.

64 "Tatarstan Wins More Independence," Commersaml, p. 5, Junc. 30, 149.3.

6.5 "Tatarstan's President Shaymiyer Interviewed," IBIS-SOV. p. 34, May 1, 1992.

66 Vera Tolz and Julia Wishnevsky, "Russia After the Reforendum," RFL/RL. Reseurch Report, p. 2, May 7, 1993.
} 


\section{Tatarstan's Trade-Related Agreements}

The long-term economic viability of Tatarstan adds credibility to its independence. "Tatarstan's GNP exceeds that of Armenia, Estonia, Latvia, Lithuania, Moldova, Tajikistan, and Turkmenistan." 67 Tatarstan certainly has the production capability in industrial goods (e.g., KamAZ trucks), and is the second largest oil producer in the former Soviet Union. ${ }^{68}$ Long-term economic viability is enhanced by external trade agreements with international trading partners. The fact that other countries have formed trade agreements with Tatarstan gives the republic legitimacy in the world economy. Economic legitimacy could translate into formal recognition of Tatarstan as an independent nation. Finally, these external agreements develop redundant trade routes that give Tatarstan geographic access to the rest of the world.

One trading partner is the neighboring republic of Bashkortostan (see Fig. 2). Although Tatarstan has a large supply of crude oil, the republic lacks the capability of refining it. The oil is refined primarily in Bashkortostan, which also refines

67 Cieorgi Vachnadzo, p. 127

68 "Tatarstan Prime Minister Discusses Production," FBIS SOV, p. 40, March 4, 1993. 


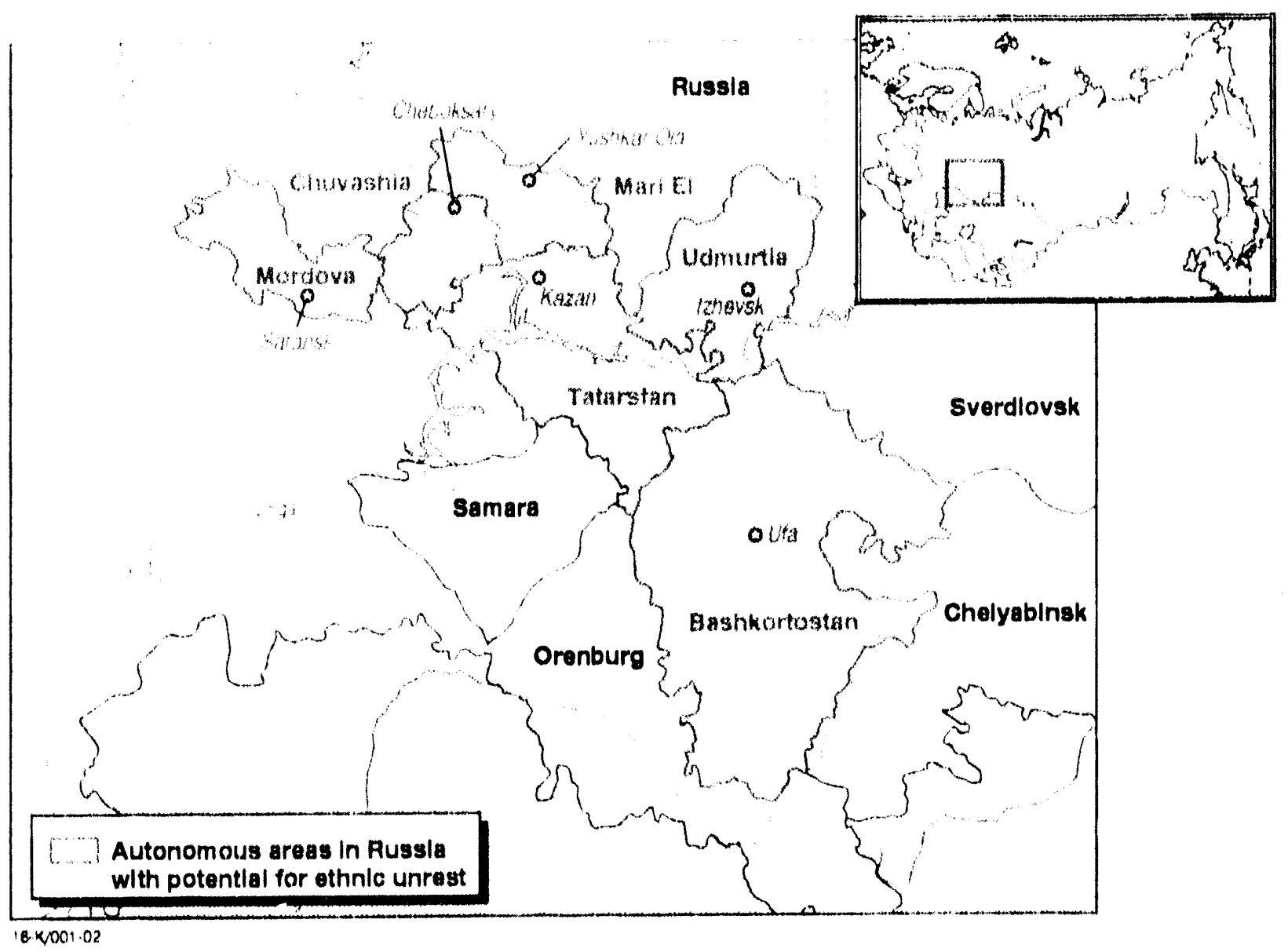

ligure 2. The Volga Region. 
80 percent of the oil for the RF. ${ }^{69}$ However, the outdated facilities in Bashkortostan are extremely inefficient. Half of the oil is lost in the refining process. ${ }^{70}$ Therefore Tatarstan, searching for a more effective refinement capability, established a trade mission in Lithuania in 1992.71 In return for oil, Tatarstan hopes to make use of an oil refinery in Lithuania that is currently not in use. This would improve refining efficiency and promote oil sales outside the RF. In addition, the agreement with Lithuania would give Tatarstan access to the Baltic Sea, and hence, European markets. For this, Tatarstan would like to use Lithuania's sea-going fleet.

Tatarstan has gained additional sea access through an agreement with the Ukrainian region, Crimea (see Fig. 1). On February 27, 1993, Crimea and Tatarstan signed an agreement in which Tatarstan would provide Crimea with oil, trucks, and other industrial products in return for access to Crimea's ports on the Black Sea and the Sea of Azov. ${ }^{72}$ In addition, Crimea would provide agricultural products and tourist access. Tatarstan's oil can reach the ports by barge traveling down the Volga River to the Volga-Don canal, through the canal into the Azov Sea, and from there into the Black Sea. This also opens new trading partners to Tatarstan, for example, Turkey, with whom the Tatars are ethnically linked. This agreement creates future possible trade outlets in the Mediterranean Sea and beyond. This agreement diminishes the difficulties of being surrounded by the RI and not being directly located on a sea or ocean.

Tatarstan also has direct access to the Caspian Sea by barge routes on the Volga River. Tatarstan safeguarded this access by forming trade relations with the Astrakhan Oblast, which is situated on the delta of the Volga river near the Caspian Sea (see Fig. 1). Tatarstan provides Astrakhan with a range of goods from automobiles to agricultural products. In return, Astrakhan provides Tatarstan with fish, meat, wool, agricultural goods, salt, natural gas condensate, and light-industrial products. ${ }^{73}$

Access to the Caspian Sea provides Tatarstan trading opportunities with Azerbaijan. This is significant because some Turkic political parties and movements within Tatarstan, such as Ittifak, are members of the Association of Turkic Peoples, which pledged support to the territorial integrity of Azerbaijan. ${ }^{74}$ Ittifak is a TatarMuslim nationalist group whose agenda includes total secession from the RF withiout any delegation of powers to the center. ${ }^{75}$ Iltifak has established a national guard and has military detachments. ${ }^{76}$ Now Ittifak has access to Azerbaijan.

69) Coorgi Vachnadze, p. 85.

70) Ibid., p. 119.

71 Ibid., p. 124.

72 "Tatarstan, Crimea Sign Cooperation Agrement," FB/S SOV, pp. 49 50, March 3, 1993.

7.3 "Tatarstan, Astrakhan Oblast Sign Cocoperation Accord," IRIS lISR, pP. 65 66, June $24,1992$.

74 "Assembly of Turkic Peoples Created," FBIS LISR, P. 24, March 17, 1992.

75 “Tatar Parties Protest at Leadership's Inactivity," Interfax Now's Agency, BBC Summary of World Brodadcasts, p. SU/1437/B/1, July 201, 1992.

76 "Tatar Party Meeting Discusse's Prospects for Independence," FBIS UISR, p. 67, November 21, 1991, 
Another arrangement that has given Tatarstan access to some sea routes is an agreement with the city of St. Petersburg and the Leningrad region. ${ }^{77}$ The agreement calls for the trade of consumer goods, the exchange of economic information, and work on joint projects. Trading with St. Petersburg gives Tatarstan access to the Gulf of Finland and the Baltic Sea (see Fig. 1).

In summary, Tatarstan has made much headway in promoting its survival as an independent country by establishing trade agreements that ensure it will not be isolated and that provide it with redundant supply routes.

\section{Political Movements}

Although the official approach of the government is moderate, there are some groups in the republic that are extreme. These groups tend more often to be Tatar nationalists than Russian nationalists. With independence, both the Russians and Tatars stand to gain economically. With the centrist approach of the government and the planned continuation of an association with the RF, the Russian minority does not fear becoming an oppressed minority, because the emphasis is on economic independence rather than ethnic liberation. The Tatar extremists believe that they lose with the centrist approach, because their primary concern is nationalism.

Astrakhan is a part of Ittifak's notion of a "Greater Tatarstan." 78 Tatars have historical links with Astrakhan that go back centuries to when the region was ruled by the Tatars, until Ivan the Terrible conquered the lands in the 1500s. The signing of a Cooperation Accord of friendship between Tatarstan and Astrakhan strengthens these ties, despite the fact that Tatars account for only $7.2 \%$ of the Astrakhan population. ${ }^{79}$ Besides Astrakhan, Ittifak claims Simbinsk, Saratov, Samara, Orenburg, the Ufa Plateau, and the Western slope of the Ural mountains, which, Ittifak contends, accounts for half of Russia's territory. ${ }^{80}$

Several of the Tatar nationalist groups do not recognize the government of Tatarstan as the official government. Rather, they support a parallel parliament called Milli Majlis, which is sympathetic to the extremists' cause. ${ }^{81}$ If Milli Majlis were the official government, they would pursue an agenda that includes the expropriation of all enterprises in Tatarstan's territory that have been sold to foreigners. ${ }^{82}$ The term foreigner also applies to any Russian who is not a citizen of Tatarstan. In addition, it would make Tatar the only official language of the

Yelena Pestrukhina, "Shakrai Puts Forth 11 Principles," Megapolis-Express, p. 13,

March 3, 1993.

77 "Tatarstan Signs Agreements with St. Petersburg," FBIS-Sov, p. 50), May 21, 1993.

78 A. Putko, "How it is Being Proposed that the Tatars Free Themselves from the 'Russian

Yoke," Current Digest of the Suviet Press, December 25, 1991.

79 "Tatarstan, Astrakhan Oblast Sign Cooperation Accord," FBIS-LISR, Pp. 65-66, June $24,1992$.

80 Ibid.

81 "Tatar Milli-Majlis Statement on ils Role in Covernment Issues," FBIS-UISR, p. 29, May 4, 1992.

82 Arytom Karapetyan, "Kuo Zadis, Tatarstan," Moscow News, January 22, 1992. 
republic. ${ }^{83}$ Currently, Russian and Tatar are both official languages. ${ }^{84} \mathrm{~A}$ third goal of the Milli Majlis is to deport all Russians who are opposed to independence. ${ }^{85}$

These minority political movements put pressure on Tatarstan's government to abandon the centrist approach. They could threaten the Tatarstan leadership's attempts for a confederal independence with the center.

\section{Conclusion}

The Federation Treaty and the draft constitution reveal the difficulties of establishing relations with different factions of a country on unequal terms. Codifying inequalities leads to resentment and the drive for the disadvantaged to acquire the privileges of the advantaged. Sustaining a stable state under such conditions could prove to be an insurmountable task. Underlying the pursuit for equality are the economic incentives gained by independence. Tatarstan serves as an example of independence driven by economics. Data on other republics suggest that Tatarstan's situation is indicative of the instability in the RF. Tatarstan is approaching independence as amicably as possible, and is trying to gain the center's acceptance, but it is striving nonetheless for independence. If Tatarstan succeeds, it could inspire other republics to follow a similar route. International recognition of Tatarstan and possibly other republics will most likely change the geographical structure of the RF.

$83 \mathrm{lbid}$.

84 "Report on Tatarstan Parliament Session Activity," FBIS-USR, p. 50, June 10, 1992.

85 Op, cit. 


\section{Appendix}

\section{Independence Activities of Several Republics}

Several other republics have been displaying their independent characters and expressing their intent to gain increased independence from the center. This appendix discusses a few of these republics and highlights their independent inclinations.

\section{Bashkortostan}

The Republic of Bashkortostan, which neighbors Tatarstan, has been following a path toward independence similar to Tatarstan's. Like Tatarstan, economic rather than nationalistic considerations are the driving force behind its independence efforts. Bashkortostan has been more successful with regard to economic independence because it has received broader concessions from the center. The center compromised to persuade Bashkortostan to sign the Federation Treaty, because the center did not want to have both Tatarstan and Bashkortostan remaining outside the federation. ${ }^{86}$ The concessions granted to Bashkortostan are contained in the "Appendix to the Federal Treaty from the Republic of Bashkortostan." Bashikortostan acquired exclusive right to the property on its territory, exclusive right to taxation, and independence in foreign activity. ${ }^{87}$ In addition, it received recognition of its judicial and legislative systems. ${ }^{88}$ This is a major breakthrough, considering that these concessions were granted by the center.

Bashkortostan also favors Tatarstan's idea of having a confederal relationship based on bilateral treaties of the mutual delegation of powers with the center. ${ }^{89}$ Bashkortostan believes that such a relationship would actually strengthen the RF, because localized control would be more effective than control centralized in Moscow. ${ }^{90}$ Therefore, Bashkortostan, like Tatarstan, does not have the goal of secession. Rather, it supports the idea of remaining associated with the center, but with an independent status. Bashkortostan expressed its opposition to centralized control by adopting a law to protect its sovereignty that insulates itself from the control of the center. The law allows Bashkortostan to suspend or ignore Russian laws that conflict with Bashkortostan's. ${ }^{91}$

\footnotetext{
86 "Federation's Concessionn to Bashkortuntan Delailed," IHIS USSR, p. 21, April 17, 1992.

87 Ibid.

sx fbid.

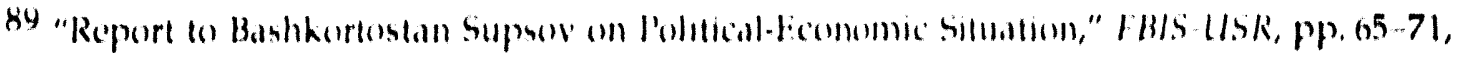
Mlay 15, 1402.

9) Ibid.

91 "Bashkortobtan Rejects Russian Dralt Comstilution," IlHIS LISR, March 27, 1942.
} 
Interestingly, Bashkortostan came close to being a member of the Commonwealth of Independent States. Before the August 1991 putsch, Bashkortostan had adopted a declaration of state sovereignty that would have made it a Union Republic. ${ }^{92}$ With the fall of the Soviet Union, it would have become an independent state. However, the putsch stopped the progress toward sovereignty, and Yeltsin's government decided that Bashkortostan was not independent. ${ }^{93}$

The center has not been supportive of the economic independence it granted to Bashkortostan. In fact, the center has actually tried to impede the efforts of Bashkortostan. For instance, Moscow ignored a request from Bashkortostan to observe whether Bashkortostan specialists were qualified to issue licenses for the oil products that Yeltsin authorized the republic to export independently. ${ }^{94}$ This caused the republic to lose time, miss deadlines, lose credibility with its trading partners, and lose some hard currency.

Because the powers granted to Bashkortostan were contained in the Federation Treaty, they technically have not been implemented. Given the center's unwillingness to be supportive of Bashkortostan, the republic decided to include its own question on the April 1993 referendum (the vote of confidence in Yeltsin). This question asked: "Do you agree that the Republic of Bashkortostan must have economic independence and treaty-based relations with the RF on the basis of the Federation Treaty and Appendix to it, in the interests of all the peoples of the Republic of Bashkortostan?"95 75.5\% of the votes affirmed this question. ${ }^{96}$ Economic independence entails the ability to pursue trade agreements, have exclusive right to the property on the territory, and have exclusive right to taxation. In addition, Bashkortostan is demanding the freedom to institute its own currency. ${ }^{97}$ Although the question on the referendum carries no legal force, it does show that Bashkortostan does not intend to let the center forget the Appendix to the Federation Treaty.

\section{Buryatia}

Buryatia supports the Federation Treaty and demands that it be incorporated into the $\mathrm{RF}$ constitution. ${ }^{98}$ However, the republic believes that the constitution should clarify that the republics are states within the federation with their own constitutions, citizenship, laws, and economic sovereignty. ${ }^{99}$ Buryatia is one of nine

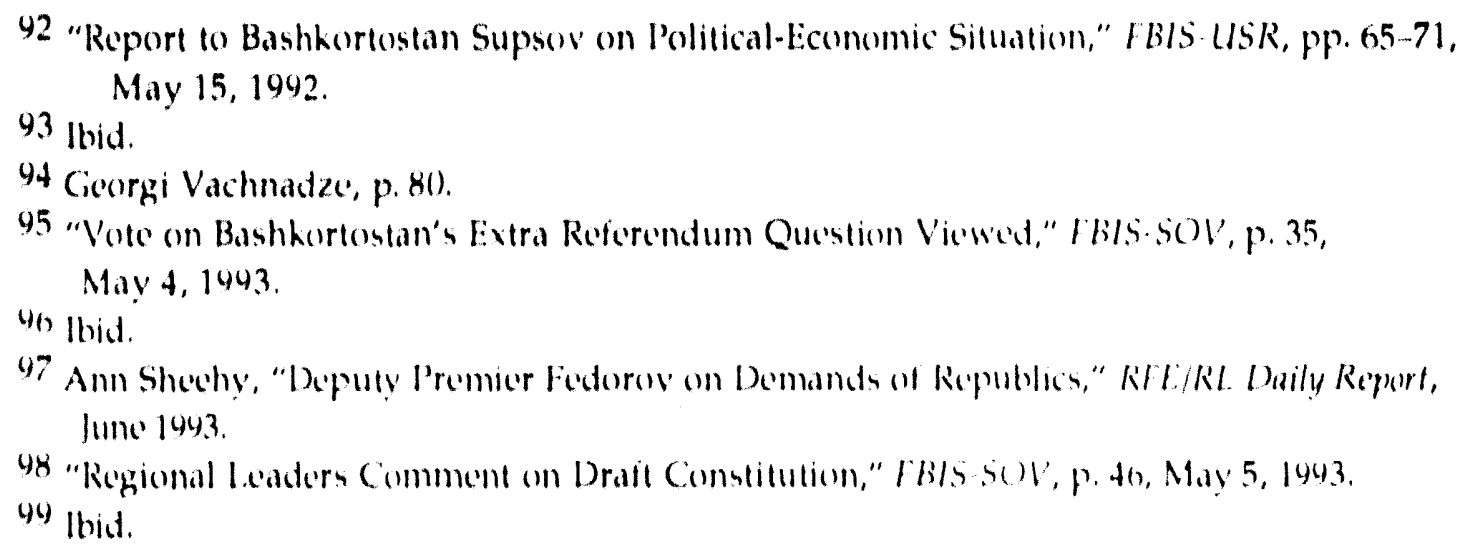


republics to hold its constituticn supreme over the $\mathrm{RF}^{\prime}$ s constitution. 100 "Since 1992 Buryatia has been a self-governing independent state and owns its land and the subsoils." 101 Therefore, Buryatia appears to support being a member of the RF while still retaining much independence. However, according to The Economist, the situation is worse. "The republics along the Mongolian border, like Tuva and Buryatia, are gradually slipping away from Moscow's control."102

\section{Udmurtia}

Valentin Tubylov, the chairman of the Udmurt Republic Supreme Soviet, expressed in February 1993 that a desire for sovereignty and independence exists, although without a strong economy the goal is not feasible. "It is not enough to declare our independence and self-sufficiency and adopt the appropriate law. Without a strong independent economy there can be no talk of any kind of sovereignty." 103 The goal of Udmurtia is not to secede from the federation. Rather, the republic demands democratic relations with the center based on "strict compliance with the Federative Treaty and bilateral agreements of the federal organs and subjects of the Federation." 104 Udmurtia recognizes that its economic status does not give it the ability to demand the relations and concessions that Tatarstan and Bashkortostan are able to demand, because "Poorer regions, which in the past relied on subsidies from the center, do not have as much bargaining power." 105

Udmurtia hopes the center will recognize that the different regions have different needs and therefore cannot all be ruled in the same way. For example, Udmurtia's economy was largely dependent on the military-industrial complex, which accounted for 85 percent of the republic's industrial production. 106 With the decreasing demand for defense products, industry in Udmurtia is devastated by the transition to a market economy. ${ }^{107}$ In addition, the center is using Udmurtia as a testing ground for conversion from defense to civilian production. ${ }^{108}$ The center deprived Udmurtia of export revenues from weapons sales, which further devastated their economy. ${ }^{109}$ Udmurtia believes that the center should be more sympathetic toward the needs of the regions, and that perhaps more localized control would be more effective, allowing the individual regions to determine the rate of their economic transition. 110

\footnotetext{
10() Vladimir Yemelyanko, "The Country Will Collapse," Moscow News, February 7, 1993.

101 Georgi Vachnadze, p. 92.

102 "Things Fall Apart," The Economist, p. 47, January 30, 1993.

103 "Udmurtia Official on Republic, Relations with Center," FBIS-USR, p. 35, May 3, 1993.

104 Ibid., p. 37.

105 "A Country of Countries," The Economist, p. 22, March 27, 1993.

106 Ceorgi Vachnadze, p. 111

107 "Udmurtia Official on Republic, Relations with Center," FBIS-USR, p. 35, May 3, 1993.

108 Georgi Vachnadze, p. 115.

109 Ibid.

110 "Udmurtia Official on Republic, Relations with Center," FBIS-USR, p. 37, May 3, 1993.
} 

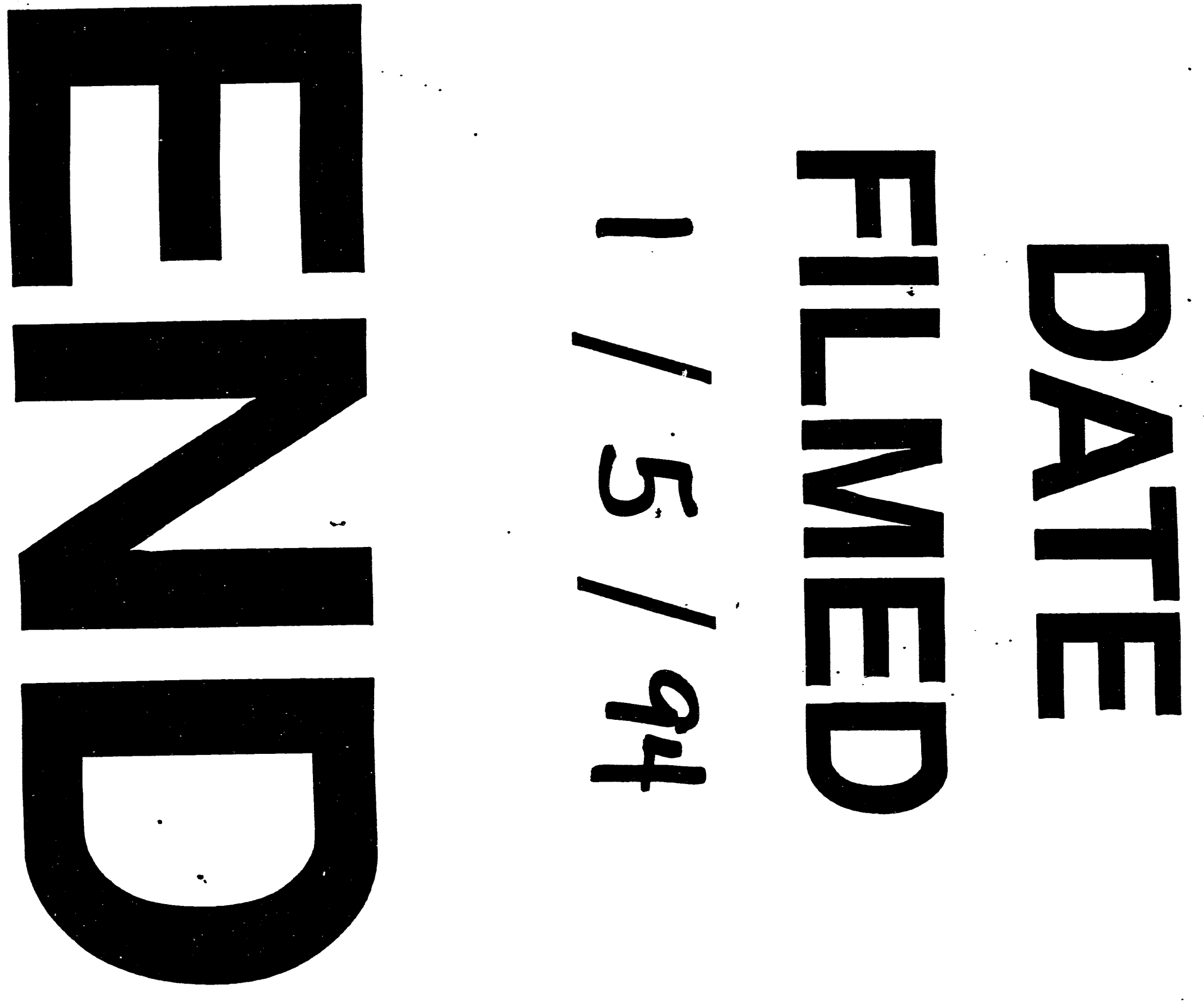


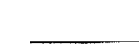

